\title{
Effect of Petroleum Products on Soil Catalase and Dehydrogenase Activities
}

\author{
Fidelis Ifeakachuku Achuba*, Patrick Nwanze Okoh \\ Department of Biochemistry, Delta State University, Abraka, Nigeria \\ Email: *achubabch@yahoo.com
}

Received 6 October 2014; revised 28 October 2014; accepted 12 November 2014

Copyright (C) 2014 by authors and Scientific Research Publishing Inc.

This work is licensed under the Creative Commons Attribution International License (CC BY). http://creativecommons.org/licenses/by/4.0/

c) (i) Open Access

\begin{abstract}
The effect of refined petroleum products on the activities of selected enzymes (catalase and dehydrogenase) was studied. There was a significant decrease $(p<0.01)$ in catalase activity. Catalase activity was higher in diesel and engine-oil treated soil after twelve days relative to petrol and kerosene. These observations indicate that the enzyme activity is the order of petrol $>$ kerosene $>$ diesel > engine oil. However, a significant increase $(p<0.01)$ was observed in dehydrogenase activity after twelve days relative to control values. Although, the refined petroleum products caused a similar pattern in the alteration of soil dehydrogenase activity, as they affected catalase activities, the general results indicate that the toxic effect is in the order of kerosene $>$ diesel $>$ petrol $>$ engine oil. On the whole the results reveal that refined petroleum products alter soil biochemistry.
\end{abstract}

\section{Keywords}

Catalase Activity, Dehydrogenase Activity, Kerosene, Diesel, Engine Oil, Petrol

\section{Introduction}

Petroleum compounds have multifarious industrial and domestic uses. They are extensively employed in the making of solvents, dry cleaning fluids quick-products, automobile fuel, household solvents, and lubricants, cosmetics, water proofing agents, cleaning agents, and specialty chemicals [1]. These activities have led to the widespread contamination of the environment. Oil spill is the major cause for the high influx of petroleum to the biosphere [2] [3]. However, other points of soil pollution with refinery products are petrol stations, car and tractor servicing parks and, seaport areas [4]. Other areas of concern are mining and distribution of petroleum-based products [5] [6]. Besides, heavier use of machinery in agriculture together with unsatisfactory care while disposing of old or used petroleum products leads to considerable pollution of the natural environment [7].

\footnotetext{
"Corresponding author.
} 
The soil is a key component of natural ecosystem because environmental sustainability depends largely on sustainable soil ecosystem [8]. When soil is polluted, the physiochemical properties are affected which may decrease its productive potentials [9]-[12]. In Nigeria, most of the terrestrial ecosystem and shoreline in oil-producing areas are important agricultural land under cultivation [13]. Any contact with petroleum and/or refined petroleum products causes damage to soil conditions of these agricultural lands, which culminates in loss of soil fertility [11] [12] [14]-[16]. Soil enzymes are important biotic components which are responsible for soil biochemical reactions [17]. The effects of petroleum hydrocarbon on soil enzyme activities are well documented [18]-[21].

Catalase activity, alongside with the dehydrogenase activities, gives information on the microbial activities in soil. Both catalase and dehydrogenase activity are very sensitive to heavy metal pollution [22]-[24]. Their values can therefore be used as a simple toxicity testing tool [25]. The aim of this study was to determine the effect of petroleum products (kerosene, diesel, engine oil and petrol in soil on soil catalase and dehydogenase activities.

\section{Materials and Methods}

Refined petroleum products of known physical properties were obtained from Warri Refining and Petrochemical Company, Warri, Nigeria. The soil (sand $84 \%$, silt $5.0 \%$, clay $0.4 \%$ and organic matter $0.6 \%$, pH 6.1 ) was obtained from a fallow land in Delta State University, Abraka. Some of the chemical properties of the soil are listed in Table 1.

Soil (1600 g) was taken in each of small size planting bags $\left(1178.3 \mathrm{~cm}^{3}, 15 \mathrm{~cm}\right.$ deep) and divided into six groups of five replicates. Groups 1 to 5 contained $0.1 \%, 0.25 \%, 0.5 \%, 1.0 \%$ and $2.0 \%(\mathrm{v} / \mathrm{w})$ respectively of each of the petroleum products while group six served as control ( $0.0 \%)$. To the first bag, $1.0 \mathrm{ml}$ of kerosene, corresponding to $0.1 \%$, was added. The petroleum products treated soil samples were mixed vigorously with the hand to obtain homogeneity of the mixture. The procedure was repeated for $0.25 \%, 0.5 \%, 1.0 \%, 1.5 \%$ and $2.0 \%$. Each treatment, including control, was replicated five times.

\subsection{Preparation of Extract and Assay of Catalase Activity}

One hundred $\mathrm{ml}$ of phosphate buffer, $\mathrm{pH} 7.4$, was added to $10 \mathrm{~g}$ of soil and stirred vigorously. The soil suspension was filtered using cheesecloth. The filtrate was centrifuged at maximum speed of $7000 \mathrm{~g}$ for $10 \mathrm{~min}$ to obtain supernatant (S1). Catalase activity was determined as described by Rani et al. [26]. Catalase breaks down hydrogen peroxide to give oxygen that oxidises potassium dichromate. The oxidation of chromate gives a chromophore that absorbs maximally at $610 \mathrm{~nm}$. The enzyme extract $(0.5 \mathrm{ml})$ was added to the reaction mixture containing $1 \mathrm{ml}$ of $0.05 \mathrm{M}$ phosphate buffer ( $\mathrm{pH} 7.5$ ), $0.5 \mathrm{ml}$ of $0.2 \mathrm{MH}_{2} \mathrm{O}_{2}, 0.4 \mathrm{ml} \mathrm{H}_{2} \mathrm{O}$ and incubated for different time period $t_{1}, t_{2}$ and $t_{3}$ for 1 minute, 2 minutes and 3 minutes respectively. The reaction was terminated after each time interval by the addition of $2 \mathrm{ml}$ of acid reagent (dichromate/acetic acid mixture) which was prepared by mixing $5 \%$ potassium dichromate with glacial acetic acid (1:3 by volume). To the control, the enzyme was added after the addition of acid reagent. All the tubes were heated for 10minutes in boiling water and the absorbance was read at $610 \mathrm{~nm}$. Catalase activity was expressed in terms of moles of $\mathrm{H}_{2} \mathrm{O}_{2}$ consumed/min.

Table 1. Physicochemical properties of test soil.

\begin{tabular}{cc}
\hline Parameters & Value \\
\hline pH & 6.09 \\
Total organic carbon, \% & 2.90 \\
Phosphorus, $\mathrm{mg} / \mathrm{kg}$ & $<0.01$ \\
Nitrogen, $\mathrm{mg} / \mathrm{kg}$ & 8.47 \\
Nitrate, $\mathrm{mg} / \mathrm{kg}$ & 9.86 \\
Cation exchange capacity, meq/100g & 0.74 \\
Sodium, $\mathrm{mg} / \mathrm{kg}$ & 9.06 \\
Potassium, $\mathrm{mg} / \mathrm{kg}$ & 6.72 \\
Calcium, $\mathrm{mg} / \mathrm{kg}$ & 2.98 \\
Magnesium, $\mathrm{mg} / \mathrm{kg}$ & 0.31 \\
\hline
\end{tabular}




\subsection{Assay of Soil Dehydrogenase Activity}

Dehydrogenase activity was determined using the method described by Tabatabai [27]. Dehydrogenases convert 2, 3, 5-triphenyl tetrazolium chloride to formazan. The asbsorbance of formazan was read spectrophotometrically at $485 \mathrm{~nm}$. Sieved soil $(1 \mathrm{gm})$ was placed in test tubes $(15 \times 100 \mathrm{~mm})$, mixed with $1 \mathrm{ml}$ of $3 \%$ aqueous (w/v) 2, 3, 5-triphenyl tetrazolium chloride and stirred with a glass rod. After $96 \mathrm{~h}$ of incubation $\left(27^{\circ} \mathrm{C}\right) 10 \mathrm{ml}$ of ethanol was added to each test tube and the suspension was vortexed for $30 \mathrm{~s}$. The tubes were then incubated for $1 \mathrm{~h}$ to allow suspended soil to settle. The resulting supernatant $(5 \mathrm{ml})$ was carefully transferred to clean test tubes using Pasteur pipettes. Absorbance was read spectrophotometrically at $485 \mathrm{~nm}$. Extinction coefficient of $15433 \mathrm{Mol} / \mathrm{cm}$ [28] was used for evaluating the concentration of formazan formed.

\subsection{Statistical Analysis}

The results were expressed as mean + SEM. All results were compared with respect to the control. Comparisons between the test and control were made by using analysis of variance (ANOVA). Differences at $p<0.01$ were considered as significant.

\section{Results}

The results of the effect of refined petroleum products on soil catalase activites after four, eight and twelve days soil treatment are presented in Figure 1 The activities of catalase in soil samples were decreased significantly $(\mathrm{p}<$ 0.01) after four days of the treatment of soil samples with kerosene, diesel, engine oil and petrol. At the highest concentrations petrol decreased catalase activity significantly $(\mathrm{p}<0.01)$ more than did engine oil, and engine oil decreased catalase significantly $(\mathrm{p}<0.01)$ activity more than did either kerosene or diesel. After eight days of treatment of soil with peroleum produts, kerosene treatment of soil resulted in significant $(p<0.01)$ decrease of catalase activity at $2 \%$ concentration compared with control. Diesel treatment of soil gave rise to a significant (p $<0.01$ ) decrease of catalase activity at $1 \%$ and $2 \%$ concentrations. However, engine oil treatment of soil resulted in significant $(\mathrm{p}<0.01)$ decrease in catalase activity in all the concentrations tested $(0.25 \%-2 \%)$. Finally, petrol treatment of soil brought about a significant increase of soil catalase activity at $0.25 \%, 0.5 \%, 1.5 \%$ and $2 \%$ compared with control. Comparing the activities of soil catalase in kerosene, diesel, engine oil and petrol treated soil; it was found to be significantly lower in all the tested concentrations in engine oil treatment of soil except at $0.25 \%$ concentration than the other petroleum products. But petrol treatment resulted in significantly higher catalase activity at $0.25 \%$ and $0.5 \%$ concentrations, than in other petroleum products treated soils

The activities of catalase after twelve days following the treatment of soil with kerosene significantly $(\mathrm{p}<$ 0.01 ) decreased catalase activity at a concentration of $0.25 \%$ but not at higher concentrations. Diesel treatment of soil resulted in decrease in catalase activity that was significant $(\mathrm{p}<0.01)$ only at $0.25 \%$ level of contamination. Engine oil treatment of soil resulted in significant $(\mathrm{p}<0.01)$ increase of catalase activity from $0.5 \%$ up to $1.5 \%$, thereafter, an additional increase in concentration brought about a significant $(\mathrm{p}<0.01)$ decrease of catalase activity relative to the control. Petrol treatment of soil resulted in a significant $(\mathrm{p}<0.01)$ decrease of catalase activity only at $0.25 \%, 1 \%$ and $1.5 \%$ concentrations compared with control. When the activities of soil catalase in petrol, kerosene, and diesel and engine oil treatment of soil are compared; it was found to be significantly higher in engine oil treatment of soil at $1 \%$ and $1.5 \%$ concentrations than the other petroleum products. However, catalase activity was significantly lower in petrol treatment of soil at $1 \%$ concentration than the other petroleum products.

The activities of soil dehydrogenase after four days following the treatment of soil samples with kerosene, diesel, engine oil and petrol are presented in Figure 2. Kerosene treatment of soil resulted in significant increase of soil dehydrogenase activity from $0.5 \%$ up to $2 \%$. Similarly, diesel treatment of soil led to a significant increase of soil dehydrogenase activity at $0.5 \%$ up to $2 \%$. Engine oil and petrol treated soils had an all round significant $(\mathrm{p}<0.01)$ increase of soil dehydrogenase activity in all the concentrations tested compared with control. When the activities of soil dehydrogenase in engine oil treatment of soil were compared with other petroleum products treated soil samples, they were found to be significantly ( $\mathrm{p}<0.01$ ) higher at $0.25 \%, 0.5 \%, 1.5 \%$ and $2 \%$ concentrations over other petroleum products. Petrol treatment of soil recorded a significantly higher activity of soil dehydrogenase only at $1 \%$ than other petroleum products. The activities of soil dehydrogenase after eight days following treatment of soil samples with kerosene, diesel, engine oil and petrol are shown in Figure 2. In 
all the concentrations tested, all petroleum products, treated soil samples resulted in significant increase ( $\mathrm{p}<$ 0.01 ) of soil dehydrogenase activity compared to control. When the activities of soil dehydrogenase in soils treated with kerosene, diesel, engine oil and petrol are compared, it was found to be significantly higher in engine oil at all levels of concentrations than the other petroleum products. The activities of soil dehydrogenase after twelve days of following treatment of soil with kerosene, diesel, engine oil and petrol are shown in Figure 6. After twelve days, kerosene treated soil resulted in significant increase $(\mathrm{p}<0.01)$ of dehydrogenase activity at $1 \%, 1.5 \%$ and $2 \%$ levels of soil contamination. Diesel treatment of soil in all the concentrations tested, gave rise to significant increase $(\mathrm{p}<0.01)$ of dehydrogenase activity from $1 \%$ to $2 \%$, while, engine oil and petrol treatment of soil samples resulted in significant $(\mathrm{p}<0.01)$ increase of dehydrogenase activity at $0.5 \%$ to $2 \%$ concentrations compared to the control. when the dehydrogenase activities of soils treated with kerosene, diesel, engine oil and petrol were compared, the activities were found to be to almost the same at each level of soil contamination except that of kerosene, at $2 \%$, which was significantly lower than the other petroleum products. On the whole, the activities of soil dehydrogenase, in all the concentrations were significantly $(p<0.01)$ higher compared to control.

\section{Discussion}

The refined petroleum products altered soil catalase activity. The activity of the enzyme decreased after four days of treatment of soil with petroleum products (Figure 1), increased by the eight day (Figure 2) at lower

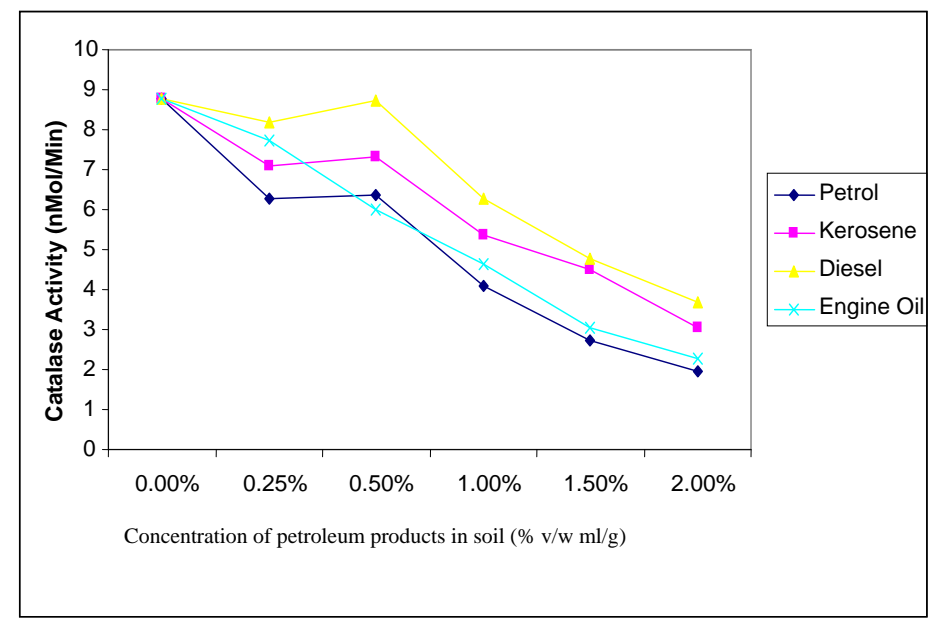

Figure 1. Dependence of catalase activity on concentration of four petroleum products in soil after four days.

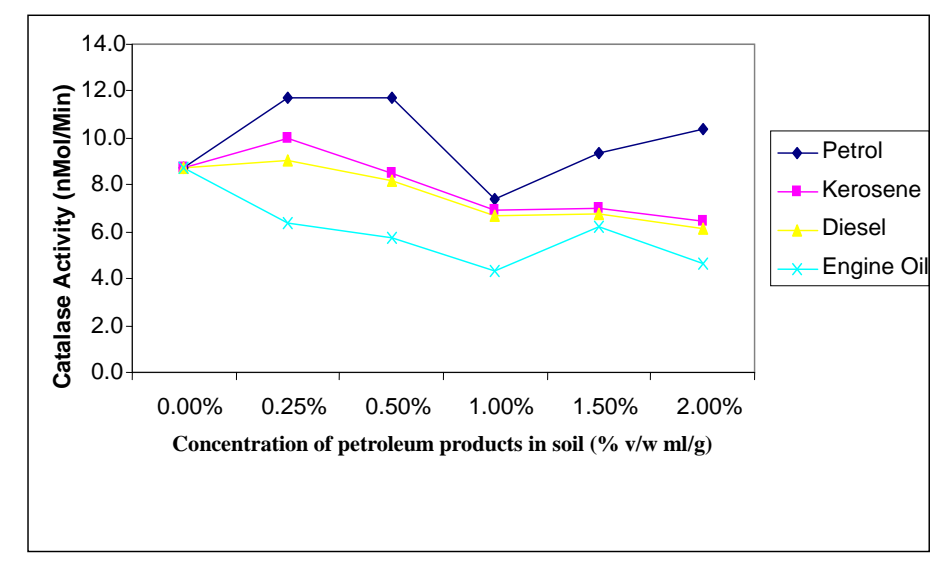

Figure 2. Dependence of catalase activity on concentration of four petroleum products in soil after eight days. 
concentrations of kerosene, diesel and petrol in soil and then started to decrease after twelve days (Figure 3) of treatment of soil. Petroleum products, when present in soil, creates an unsatisfactory condition for soil organisms, mainly due to poor aeration, immobilization of soil nutrients and lowering of soil $\mathrm{pH}$ which culminates in petroleum mediated reduction in the number of hydrocarbon degrading microorganisms [11] [15] [17] [19] [29]. This may be the basis for decrease in catalase activity after four days of treatment. Decrease in catalase activity when soil is exposed to petroleum was previously reported [19]. However, the increase in the activity of the enzyme after eight days (Figure 2) could be predicated on increased microbial activity towards biodegradation of available petroleum hydrocarbon. This might explain why the activity of the enzyme started to decrease after twelve days of incubation with petrol and kerosene (Figure 3). Earlier reports indicated that there is a decrease in catalase activity after biodegradation has decreased [30]-[32]. However, the enzyme activity was higher in diesel and engine oil treated soil samples after twelve days relative to petrol and kerosene. These observations indicate that biodegradation was in the order of petrol $>$ kerosene $>$ diesel $>$ engine oil.

Earlier reports indicated that soil polluted with petroleum hydrocarbon experienced increased dehydrogenase activity [18] [19]. The result of the current investigation agrees with this fact. The activity of the enzyme increased after four (Figure 4) and eight days of post treatment (Figure 5) with the four refined petroleum products (petrol, kerosene, and diesel and engine oil). However, the enzyme activity decreased after twelve days (Figure 6) in all the soil treated with the four refined petroleum products. The increase in enzyme activity has been attributed to the involvement of certain microorganisms in the metabolism of hydrocarbons whereas; the

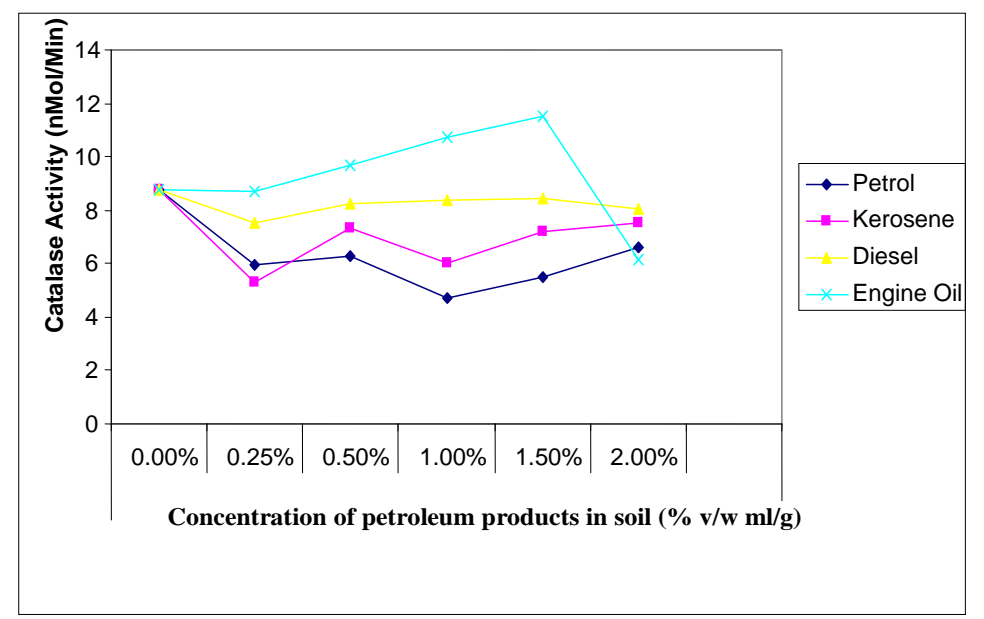

Figure 3. Dependence of catalase activity on concentration of four petroleum products in soil after twelve days.

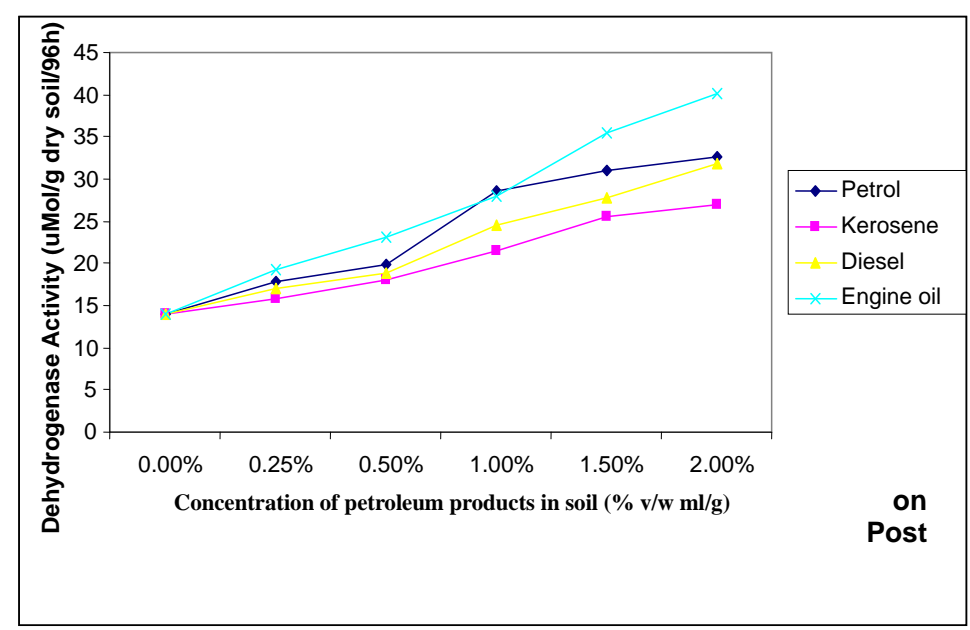

Figure 4. Dependence of dehydrogenase activity on concentration of four petroleum products in soil after four days. 


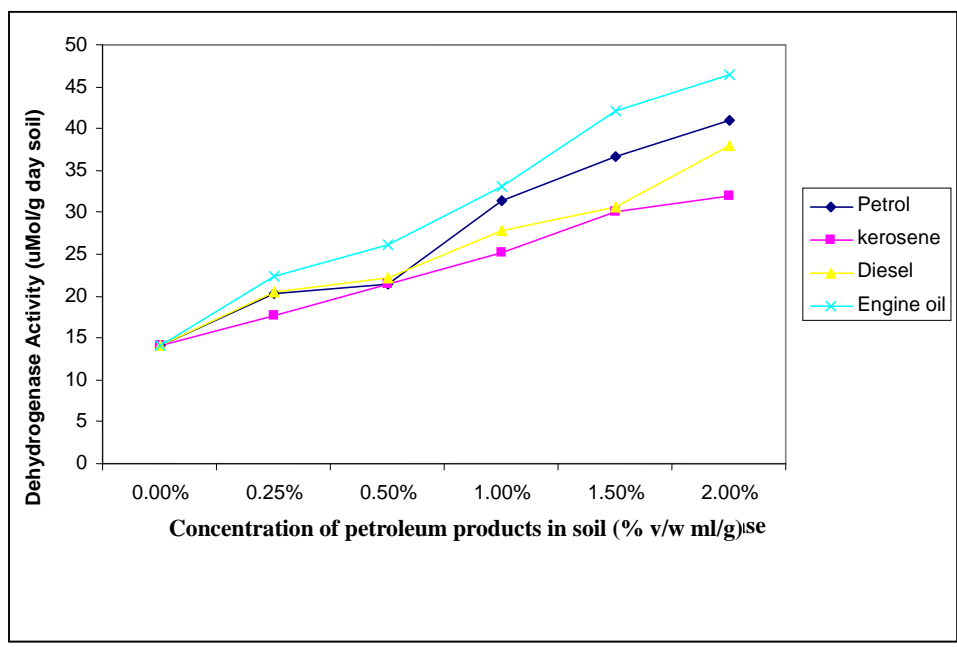

Figure 5. Dependence of dehydrogenase activity on concentration of four petroleum products in soil after eight days.

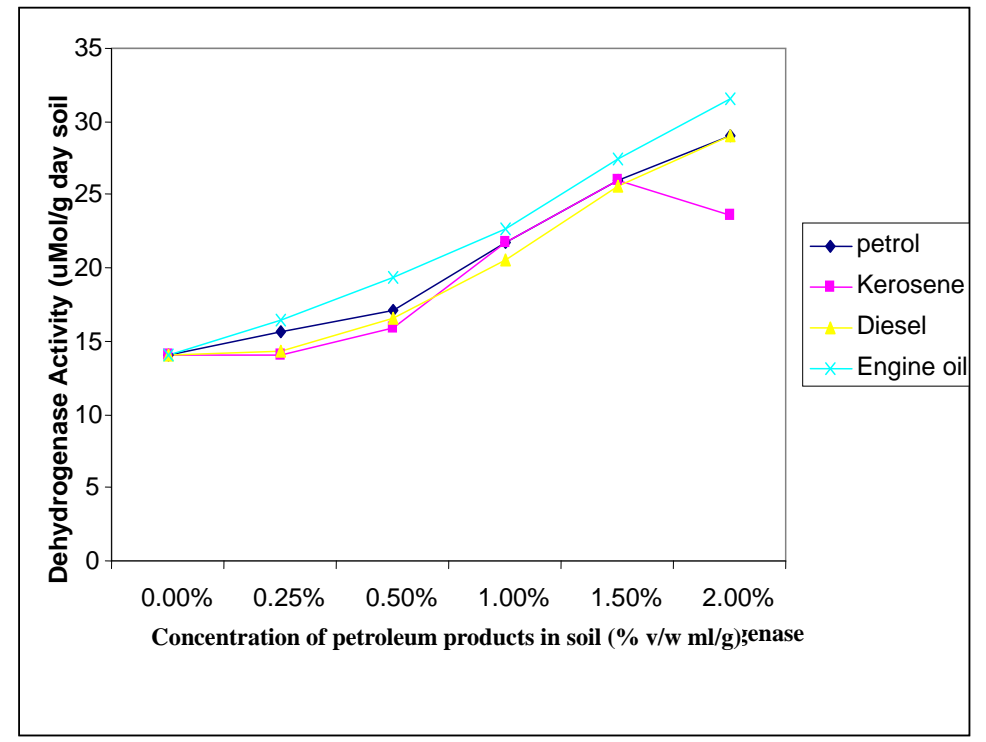

Figure 6. Dependence of dehydrogenase activity on concentration of four petroleum products in soil after twelve days.

decrease in the enzyme activity after twelve days of incubation could be due to decease in petroleum content of the soil. Decrease in soil dehydrogenase activity after biodegradation of petroleum has been reported [33] [34]. Although, the refined petroleum products caused a similar pattern, as they affect catalase activity, in the alteration of soil dehydrogenase activity, the general results seem to reveal that the toxicity effect is in the order of kerosene > diesel > petrol > engine oil. The toxicity of kerosene and diesel was reported earlier [20] [35].

\section{Conclusion}

In conclusion, it is pertinent to say that kerosene is more toxic to soil microorganisms, by decreasing the soil enzyme activities, in short term. However, engine oil stayed longer in the soil compared to the other three refined petroleum products, as reflected by sustained dehydrogenase after four days of post treatment.

\section{References}

[1] Kenny, J., Kutcherov, V., Bendeliani, N. and Alekseev, V. (2002) The Evolution of Multi-Component System of High 
Pressures: VI. The Thermodynamic Stability of the Hydrogen Carbon System: The Genesis of Hydrocarbon and the Origin of Petroleum. Proceeding of the National Academic of Sciences USA, 99, 10976-10981.

[2] Achi, C. (2003) Hydrocarbon Exploration, Environmental Degradation and Poverty. The Nigeria Delta Experience. Diffuse Pollution Conference, Dublin.

[3] Tolulope, A.O. (2004) Oil Exploration and Environmental Degradation. The Nigerian Experience. Environmental Informatics Archives, 2, 387-393.

[4] Michalcewicz, W. (1995) Wply is oleju napadewo-godo silnikow Dielsa m liczbnosc batkeri gryzbow promiienowciow oraz biomase mikoorg-anizmow glebowych. Rocz. Panstw. Zakl. Hig., 46, 91-97.

[5] Song, H. and Bartha, R. (1990) Effects of Jet Fuel Spills in the Microbisl Community of Soil. Applied and Environmental Microbiology, 56, 646-651.

[6] Jorgensen, K.S., Purstinen, J. and Sourti, A.M. (2000) Bioremediation of Petroleum Hydrocarbon-Contaminated by Compositing in Biophiles. Environmental Pollution, 107, 245-254. http://dx.doi.org/10.1016/S0269-7491(99)00144-X

[7] Odjegba, V.J. and Sadiq, A.O. (2002) Effect of Spent Engine Oil on the Growth Parameters, Chlorophyll and Protein Levels of Amaranthus hybridus L. The Environmentalist, 22, 23-28. http://dx.doi.org/10.1023/A:1014515924037

[8] Adriano, O.C., Chopecka, A. and Kaplan, K.I. (1998) Role of Soil Chemistry in Soil Remediation and Ecosystem Conservation. Soil Science Society of America, Special Publication, Madison, 361-386.

[9] Osuji, L.C., Adesiyan, S.O. and Obute, G.C. (2004) Post Impact Assessment of Oil Pollution in the Agtada West Plain of Niger Delta Nigeria: Field Reconnaissance and Total Extractable Hydrocarbon Contact. Chemistry \& Biodiversity, 1, 1569-1577. http://dx.doi.org/10.1002/cbdv.200490117

[10] Osuji, L.C., Inioborg, O.I. and Ojinnata, C.M. (2006) Preliminary Investigation of Mgbede-20 Oil Polluted Site in Niger Delta Nigeria. Chemistry \& Biodiversity, 3, 568-577. http://dx.doi.org/10.1002/cbdv.200690060

[11] Osuji, L.C. and Nwoye, L. (2007) An Appraisal of the Impact of Petroleum Hydrocarbons on Soil Fertility; the Owaza Expectation. African Journal of Agricultural Research, 2, 318-324.

[12] Wyszkowska, J., Kuncharki, J., Jastrazabska, E. and Hlasko, A. (2001) The Biological Properties of the Soil as Influenced by Chromium Contamination. Polish Journal of Environmental Studies, 10, 37-42.

[13] Egborge, A.B.M. (1994) Water Pollution in Nigeria: Bio-Diversity and Chemistry of Warri River. Ben Miller Publication, Warri.

[14] Sztompka, E. (1999) Biodegradation of Engine Oil in Soil. Acta Microbiologica Polonica, 489, 185-196.

[15] Atuanya, E.I. (1987) Effects of Waste Engine Oil Pollution on Physical and Chemical Properties of the Soil. Nigerian Journal of Applied Science, 55, 155-176.

[16] Amadi, A., Abbey, S.D. and Nma, A. (1996) Chronic Effect of Oil Spill on Soil Properties and Michroflora of Rainforest Ecosystem in Nigeria. Water, Air, and Soil Pollution, 86, 1-11. http://dx.doi.org/10.1007/BF00279142

[17] Zahir, A.Z., Malik, M.A.R. and Arshad, M. (2001) Soil Enzymes Research: A Review. Journal of Biological Sciences, 1, 299-301. http://dx.doi.org/10.3923/jbs.2001.299.307

[18] Li, H., Zhang, Y., Zhang, C.G. and Chen, G.X. (2005) Effect of Petroleum-Containing Wastewater Irrigation on Bacterial Diversities and Enzymatic Activities in a Paddy Soil Irrigation Area. Journal of Environmental Quality, 34, 1073-1080. http://dx.doi.org/10.2134/jeq2004.0438

[19] Achuba, F.I. and Peretiemo Clarke, B.O. (2008) Effect of Spent Engine Oil on Soil Catalase and Dehydrogenase Activities. International Agrophysics, 22, 1-4.

[20] Wyszkowska, J., Kuncharski, J. and Waldowska, E. (2002) The Influence of Diesel Oil Contamination on Soil Microorganism and Oat Growth. Rostlinna Vyroba, 48, 58-62.

[21] Wyszkowska, J. and Kuchaarski, J. (2000) Biochemical Properties of Soil Contaminated by Petrol. Polish Journal of Environmental Studies, 9, 479-485.

[22] Naplekova, N.N. and Bulavko, G.I. (1983) Enzyme Activity of Soils Polluted by Lead Compounds. Soviet Soil Science, 15, 33-38.

[23] Perez, M.M. and Gonzalez, C.S. (1987) Effect of Cadmium and Lead on Soil Enzyme Activity. Review of Ecology and Biology Solutions, 1, 11-18.

[24] Wilkes, B.M. (1991) Effects of Single and Successive Addition of Cd., Ni and Zn on Carbon Dioxide Evolution and Dehydrogenase Activity in Sandy Soil. Biology and Fertility of Soils, 11, 34-37. http://dx.doi.org/10.1007/BF00335831

[25] Rogers, J.C. and Li, S. (1985) Effect of Metals and Other Inorganic Ions on Soil Microbial Activity. Soil Dehydrogenase Assay as a Simple Toxicity Test. Bulletin of Environmental Contamination and Toxicology, 34, 858-865. http://dx.doi.org/10.1007/BF01609817

[26] Rani, P., Meena Unni, K. and Karthikeyan, J. (2004) Evaluation of Antioxidant Properties of Berries. Indian Journal of 
Clinical Biochemistry, 19, 103-110. http://dx.doi.org/10.1007/BF02894266

[27] Tabatabai, M.A. (1982) Soil Enzymes, Dehydrogenases. In: Miller, R.H. and Keeney, D.R., Eds., Methods of Soil Analysis. Part 2. Chemical and Microbiolgical Properties, Agronomy Monograph, No. 9, ASA and SSSA, Madison.

[28] Dushoff, I.M., Payne, J., Hershey, F.B. and Donaldson, R.C. (1965) Oxygen Uptake Tetrazolium Reduction during Skin Cycle of Mouse. American Journal of Physiology, 209, 231-235.

[29] Maila, M.P. and Cloete, T.E. (2005) The Use of Biological Activities to Monitor the Removal of Fuel Contaminants -Perspectives to Monitoring Hydrocarbon Contamination: A Review. International Biodeterioration \& Biodegradation, 55, 1-8. http://dx.doi.org/10.1016/j.ibiod.2004.10.003

[30] Frankenberger, W.T. and Johansson, J.B. (1982) Influence of Crude Oil and Refined Petroleum Products on Soil Dehydrogenase Activity. Journal of Environmental Quality, 11, 602-235. http://dx.doi.org/10.2134/jeq1982.00472425001100040010x

[31] Van der Waarde, J.J., Dijkhuis, E.J., Henssen, M.J.C. and Keuing, S. (1995) Enzyme Assays as Indicators for Bioremediation. In: Hinchee, R.E., Douglas, G.S. and Ong, S.K., Eds., Monitoring and Verification of Bioremediation, Batelle Press, Columbus, 59-63.

[32] Schinner, F., Ohlinger, R. and Margesin, R. (1996) Methods in Soil Biology. Springer Press, Berlin. http://dx.doi.org/10.1007/978-3-642-60966-4

[33] Janke, S., Schamber, H. and Kunze, C. (1992) Beeinflussung der Biodenbiologischen Aktivat durch Heizol. Angewandte Botanik, 66, 42-45.

[34] Margesin, R. and Schinner, F. (1997) Bioremediation of Diesel-Oil Contaminated Alpine Soil at Low Temperatures. Applied Microbiology and Biotechnology, 47, 462-468. http://dx.doi.org/10.1007/s002530050957

[35] Wemedo, S.A., Obire, O. and Ijogubo, O.A. (2002) Myco-Flora of Kerosene Polluted Soil in Nigeria. Journal of Applied Sciences and Environmental Management, 6, 14-17. 
Scientific Research Publishing (SCIRP) is one of the largest Open Access journal publishers. It is currently publishing more than 200 open access, online, peer-reviewed journals covering a wide range of academic disciplines. SCIRP serves the worldwide academic communities and contributes to the progress and application of science with its publication.

Other selected journals from SCIRP are listed as below. Submit your manuscript to us via either submit@scirp.org or Online Submission Portal.
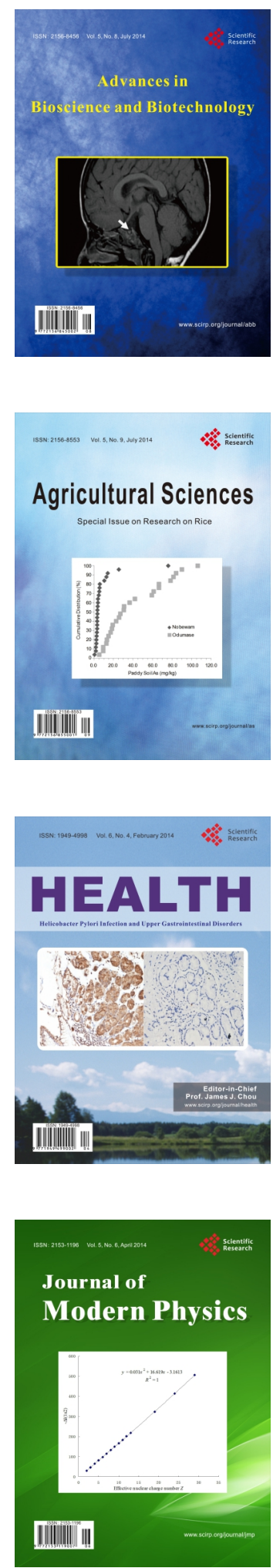
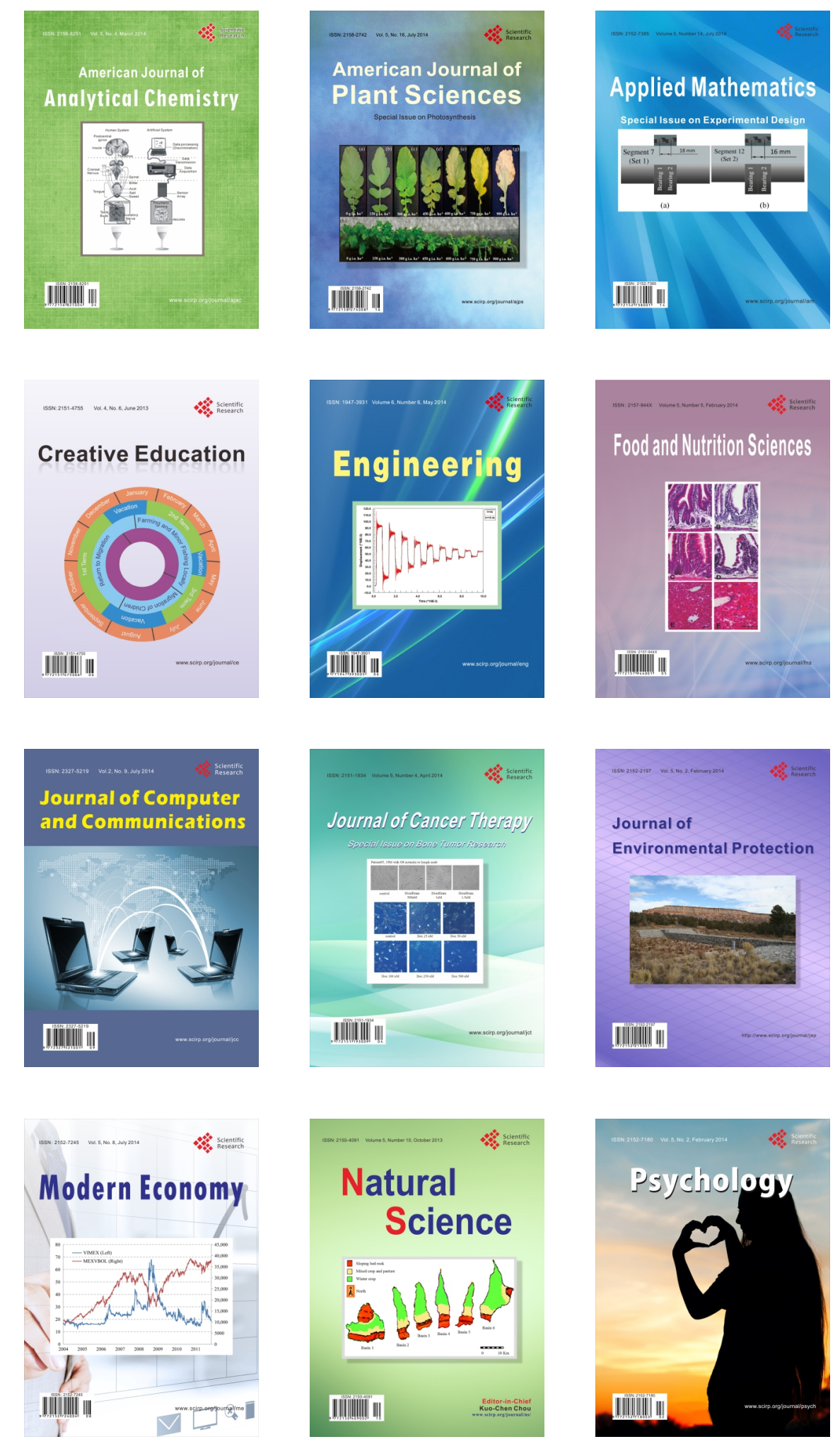